\title{
ASSESSMENT OF THE NAVIGATION SITUATION \\ IN THE DECISION SUPPORT SYSTEM FOR NAVIGATOR
}

\author{
ФОРМУВАННЯ ВАНТАЖНОГО ПЛАНУ \\ КОНТЕЙНЕРОВОЗА ЗГІДНО ЛОГІЧНИХ ПРАВИЛ \\ ЗАВАНТАЖЕННЯ-ВИВАНТАЖЕННЯ
}

\author{
Andrii Ben ${ }^{1}$ \\ Anton Fedorov ${ }^{2}$
}

DOI: https://doi.org/10.30525/978-9934-588-15-0-52

Abstract. Purpose. The article deals with the creation of automated systems for managing cargo operations of container ships. Method. The main idea of the scientific research is to study the features of the process of loading-unloading of a container ship during its multi-port going's (sequential enter to several ports during the same route). This raises the problem of "shifting", i.e. the need to move some containers on board a vessel to accommodate others. The proposed method of placing containers on the basis of logical rules of loading and unloading allows to reduce the time of stay of the vessel in port by reducing the number of "shifting" operations, which has a positive effect on the economic performance of a container ship. Scientific novelty. The mathematical model of loading of a container ship on the basis of logical rules is developed that allows to take into account simultaneously the multiportity of execution of trip of the vessel and technological limitations of formation of cargo plan due to the peculiarities of their placement on the ship. The model of formation of the optimal cargo plan of the ship, taking into account the sequence of approach to the ports during the trip, is proposed. Practical importance. In the practical side, this work is aimed at creating a software product, the use of which will allow to solve an important scientific and applied task in the field of application of information technologies in navigation - increase the

${ }^{1} \mathrm{PhD}$ of Technical Sciences, Assistant Professor,

Vice-rector of Research,

Kherson State Maritime Academy, Ukraine

${ }^{2}$ Postgraduate Student,

Kherson State Maritime Academy, Ukraine 
efficiency and safety of container transportation due to the introduction of ACCOMS. Results. Key areas of research in this field are identified. It has been shown that the creation of an automated containerized cargo operations management system (ACCOMS) will simultaneously solve a complex of cargo operations management tasks, which will reduce the time required to perform them and increase the economic efficiency of a vessel's trip. Particularly effective is the application of the proposed approach when it is applied to multi-port transportations carried out by container ships with a small number of containers (feeder transportation).

\section{1. Ветуп}

Контейнерні перевезення - економний і надійний спосіб транспортування великих партій товарів. Контейнерні вантажоперевезення $є$ одним з найнадійніших способів транспортування вантажу, що дозволяє забезпечити товару високу безпеку. Перевезення вантажу у контейнерах має ряд переваг, головна з яких - відсутність перевантажень товару при зміні транспортного засобу. Завдяки цьому досягається значна економія коштів при можливості гнучкого і ефективного поєднання різних видів транспорту в процесі доставки вантажу. До переваг морських контейнерних перевезень також можна віднести низьку, в порівнянні з більшістю інших видів транспорту, собівартість перевезень, велику вантажопідйомність морських суден, що дозволяє перевозити значні партії вантажу а також практично необмежену пропускну здатність морських шляхів [1, p. 145; 2, р. 1; 3, p. 374; 4, p. 3].

Перевезення різних промислових товарів і готових товарів широкого споживання в стандартних контейнерах - 20-foot equivalent unit (TEU), - поступово стає пріоритетним методом доставки вантажів, вибір якого обумовлений чотирма перевагами [5, р. 1436]:

- відсутністю необхідності працювати з вантажем безпосередньо, оскільки товари знаходяться в запломбованому контейнері;

- економією при перевезеннях завдяки ефекту масштабу;

- зручністю і економією часу при поєднанні з іншими видами транспорту;

- швидкістю і своєчасністю доставки.

Разом з тим, при плануванні контейнерних перевезень часто виникають різні проблеми, пов'язані з раціональним розміщенням вантажу 
на судні, що забезпечує ефективність операцій навантаження розвантаження в портах маршруту, об'ємом і вагою вантажу, що перевозиться, а також з обмеженнями при розміщенні його в трюмах і на палубі, відповідним вимогам безпеки судна.

Розміщення вантажу впливає на провізну спроможність судна не тільки через ступінь використання вантажопідйомності і вантажомісткості, а й своїм впливом на швидкість ходу і продуктивність вантажних робіт. При невдалому розміщенні вантажів судно набуває небажаного диференту, відчуває посилену хитавицю і вібрацію, можлива сильне затоплення палуб. Ці обставини знижують швидкість судна, збільшують небезпеку штормових пошкоджень і сприяють виникненню аварійних ситуацій.

\section{2. Актуальність дослідження}

При здійсненні вантажних операцій на контейнеровозі вони доволі часто здійснюються за принципом «останній завантажений - перший вивантажений», що призводить до формування неоптимального вантажного плану судна. Побудова технологічно обумовлених ланцюжків завантаження-вивантаження контейнерів, особливо, якщо маршрут судна проходить через кілька портів, призводить до виникнення проблеми так званого «шифтінга», тобто нераціональних вантажних операцій завантаження-вивантаження контейнерів на судно з метою вилучення лише потрібних в завданому порту контейнерів.

Як наслідок, контейнери, розташовані нагорі штабелю, повинні бути переміщені, щоб дозволити розвантаження контейнерів, розташованих під ними. Згідно [5, p. 1433], плата за переміщення (шіфтінгу) контейнерів може бути високою, складаючи близько 200 доларів США за переміщення одного контейнера. Таким чином, метою планування розміщення вантажу на контейнеровозах є мінімізація кількості непотрібних переміщень.

Зменшення кількості «шифтінга» позитивно впливає на економічні показники перевезення контейнерних вантажів, тому являє собою актуальну наукову та практичну задачу сучасного судноводіння [6, p. 404].

Метою дослідження є розробка математичної моделі завантаження судна-контейнеровоза, що забезпечує зменшення впливу шифтінга контейнерів, і як наслідок сприяє зниженню економічних витрат на виконання рейсу. 


\section{3. Виклад основного матеріалу дослідження}

Загальний вигляд судна-контейнеровоза та масиву контейнерів наведений на рисунку 1. Для побудови математичної моделі завантаження судна, без втрати структури оптимізаційної задачі розміщення контейнерів контейнеровоза в цілому, будемо вважати, що:
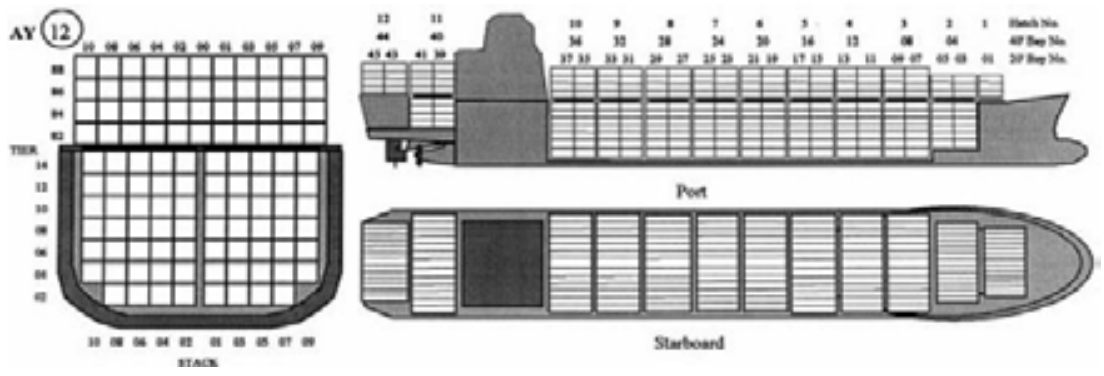

\section{Рис. 1. Загальний вигляд судна-контейнеровоза та масиву контейнерів}

1) контейнерний масив контейнеровозу має прямокутний формат $\mathrm{i}$ може бути представлений матрицею з рядками $(r=1,2, \ldots, R)$, стовпчиками $(c=1,2, \ldots, C)$ і беями $(d=1,2, \ldots, D)$, з максимальною ємністю $R \times C \times D$ контейнерів;

2) контейнери на судні є однакового (або подвійного) розміру та ваги;

3) судно починає завантажуватися в порту 1, куди воно приходить порожнім;

4) судно відвідує порти $2,3, \ldots, N$ таким чином, що воно буде пустим в останньому порту, оскільки судно виконує рейс, в якому останній порт $\mathrm{N} є$ портом його відходу;

5 ) в кожному з портів $i=2, \ldots, N-1$, судно додатково може бути завантажено контейнерами, призначенням яких є порти $i+1, \ldots, N$;

6) контейнеровоз перевозить всі контейнери з порту в порт ніколи не досягаючи при цьому максимально можливої кількості контейнерів на судні.

Кількість контейнерів, що завантажуються в кожному із портів визначається транспортною матрицею $T(N-1) \times(N-1)$. Таким чином можемо сформулювати оптимізаційну задачу завантаження контейнеровоза у вигляді: 


$$
\begin{aligned}
& f(x)=\alpha \varphi_{\cdot_{1}}(x)+(1-\alpha) \varphi_{2}(y) \\
& i=1, \ldots, N-1, \quad j=i=1, \ldots, N \\
& \sum_{v=i+1}^{j} \sum_{r=1}^{R} \sum_{c=1}^{C} \sum_{d=1}^{D} x_{i j v}(r, c, d)-\sum_{k=1}^{i-1} \sum_{r=1}^{R} \sum_{c=1}^{C} \sum_{d=1}^{D} x_{k i j}(r, c, d)=T_{i j} \\
& i=1, \ldots, N-1, \quad j=i+1, \ldots, N \\
& \sum_{k=1}^{i} \sum_{j=i+1}^{N} \sum_{v=i+1}^{j} x_{k j v}(r, c, d)=y_{i}(r, c, d) \\
& i=1, \ldots, N-1, \quad r=1, \ldots, R \quad c=1, \ldots, C \quad d=1, \ldots, D \\
& y_{i}(r, c, d)-y_{i}(r+1, c, d) \geq 0 \\
& i=1, \ldots, N-1, \quad r=1, \ldots, R-1 \quad c=1, \ldots, C \quad d=1, \ldots, D \\
& \sum_{i=1}^{j-1} \sum_{p=j}^{N} x_{i p j}(r, c, d)+\sum_{i=1}^{j-1} \sum_{p=j+1}^{N} \sum_{v=i+1}^{p} x_{i p v}(r+1, c, d) \leq 1 \\
& j=2, \ldots, N, \quad r=1, \ldots, R-1 \quad c=1, \ldots, C \quad d=1, \ldots, D \\
& x_{i j v}(r, c, d)=0 \quad \text { або } 1, \quad y_{i}(r, c, d)=0 \quad \text { або } 1
\end{aligned}
$$

де бінарна змінна $x_{i j v}(r, c, d)$ визначається наступним чином: якщо в порту $i,(r, c, d) \in$ контейнер, адресатом якого $є$ порт $\mathrm{j}$ і цей контейнер був переміщений в порту $\mathrm{v}$, то змінна приймає значення 1, в іншому випадку вона приймає значення 0.

Термін місце $(r, c, d)$ представляє являє собою рядок $r$, стовпець $c$ для бея $d$ контейнеровозу. Аналогічно, змінна $y_{i}(r, c, d)$ визначається наступним чином: якщо в порту і, місце $(r, c, d)$ містить контейнер, то змінна приймає значення 1 , в іншому випадку вона приймає значення 0.

Цільова функція (1) складається 3 двох складових: перша - загальна вартість переміщення контейнера $i$, друга, кількість шифтінгу в кожному порту. Передбачається, що для всіх портів, вартість шифтінга контейнеру однакова і дорівнює одиниці.

Два компоненти, що складають цільову функцію (1) визначають два критерії оптимізації: перший - це функція кількості переміщених контейнерів, $\varphi_{1}(\mathrm{x})$, а другий - залежить від того, як контейнерні перевезення організовуються в кожному порту, $\varphi_{2}(\mathrm{x})$. Ці два компоненти 
об'єднуються значеннями, заданими кожною вагою $\alpha$ та $(1-\alpha)$ таким чином, що формують двонаправлену структуру оптимізації.

Обмеження (2) пов'язане послідовністю 3 завантаження контейнера. Іншими словами, загальна кількість контейнерів на судні в порту повинна дорівнювати кількості контейнерів, які були завантажені в усіх портах $p=1,2, \ldots, i$ мінус загальна кількість контейнерів, вивантажених у всіх портах $p=1,2, \ldots, i$.

Обмеження (3) вимагає, щоб кожне місце $(r, c, d)$ контейнеровоза завжди займало не більше одного контейнера.

Обмеження (4) пов'язано з фізичним зберіганням контейнерів на судні, i вимагає, щоб для кожного контейнера в рядку $r+1$, існував ще один контейнер у рядку $r$ для всіх $r=1, \ldots, R-1$.

Обмеження (5) визначає, як контейнер може бути вивантажений 3 судна в порту $j$, таким чином, щоб, якщо контейнер займає позицію $(r, c, d)$ в порту $j$, і він буде вивантажений, то не існує контейнерів вище нього, або таки контейнери вже були вивантажені у попередніх портах.

Приймаючи до уваги той факт, що сучасний контейнеровоз зазвичай перевозить кілька тисяч контейнерів, а вищенаведена оптимізаційна задача динамічного програмування є $N P$-повною, розв'язання ії традиційними методами вкрай ускладнено і потребує евристичних підходів.

В ході аналізу робіт, присвячених створенню моделей і алгоритмів роз-міщення контейнерів на судні і терміналі було визначено, що для вирішення подібних завдань використовуються, в основному, евристичні підходи, а саме: ітераційний локальний пошук (iterative local search, ils); спрямований локальний пошук (guided local search, gls); пошук зі змінною околицею (variable neighborhood search, vns); імовірнісний жадібний алгоритм (grasp); еволюційний алгоритм (evolutionary algorithm, ea); генетичний алгоритм (genetic algorithms, ga); алгоритм оптимізації мурашиної колонії (ant colony optimization, асо); імітація відпалу (simulated annealing, sa); пошук із заборонами (tabu search, ts).

Проведений аналіз наукових праць дозволяє стверджувати, що для вирішення поставленої задачі найбільш доцільно застосовувати методи еволюційного програмування у вигляді генетичних алгоритмів [9, p. 22; 10, p. 586].

При цьому також з'являється можливість її додаткового уточнення і ускладнення шляхом введення додаткових обмежень по вазі, розмірам 
контейнерів, та заздалегідь визначеним місцям розташування окремих груп контейнерів на судні, наприклад рефрижераторних.

Метою дослідження $є$ розробка математичної моделі завантаження судна-контейнеровозу, що забезпечує зменшення впливу шифтінга контейнерів, і як наслідок сприяє зниженню економічних витрат на виконання рейсу.

Порівняльний аналіз досліджень, проведених різними авторами, показує, що ефективним методом вирішення проблеми є комбінований підхід, заснований на формуванні оптимального плану завантаження контейнеровозу з використанням логічних правил завантаження-вивантаження та послідуючим застосуванням евристичних методів розв'язку оптимізаційної задачі. Зазначений підхід можна краще пояснити, якщо розглянути контейнеровоз у вигляді графу, як наведено на рисунку 2.

На рис 2 вузол $p$ являє собою порт, в якому відбуваються процеси завантаження та вивантаження судна. Стан контейнеровозу змінюється коли він заходить та виходить 3 порту р. Зазначені зміни відображаються у вигляді дуг $x_{p}$ та $x_{p+1}$, відповідно. Стан хр перетворюється на $x_{p+1}$ відповідно до двох наступних рішень.

1. Якщо існуючі контейнери вивантажуються в порту $p$. Це рішення може бути представлено як $u_{p}$. Воно може бути розглянуто як сукупність двох змінних:

- змінна $q_{p}$ визначає контейнери, які повинні бути вивантажені, оскільки порт р є портом їх призначення, або якщо вони блокують собою інші контейнери, призначенням яких є порт $p$.

- змінна $v_{p}$ визначає контейнери, які повинні бути вивантажені для кращого розташування контейнерів на судні, що забезпечить змен-

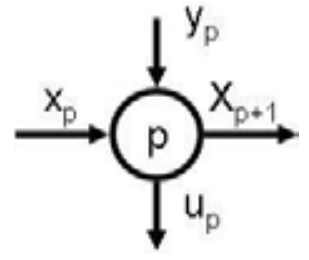

Рис. 2. Вузол і дуги

графу процесу завантаження контейнеровоза шення шифтінгу (переміщення контейнерів) при заходженні судна в наступні порти.

2. Як перезавантажити контейнери судна 3 порту $1, \ldots, p-1$, місцем доставки яких є порти $p+1, \ldots, p$, і як завантажувати контейнери $з$ порту $p$, які будуть перевозитися в наступні порти. Таке рішення визначається змінною $y_{p}$.

Слід зазначити, що $q_{p}$ та $v_{p}$ можуть істотно змінюватись в залежності від кількості контейнерів, що будуть перезавантажені на судно. 
Інакше кажучи, це гарантує, що розташування в контейнеровозі при виході з кожного порту $p\left(x_{p+1}\right)$ залежить від розташування контейнерів, коли судно прибуває до порту $p\left(x_{p}\right)$, плюс кількість контейнерів, які завантажуються або вивантажуються у порту $p$.

Програмна реалізація процесу розміщення контейнерів на судні потребує визначення двох складових:

- оскільки розміщення контейнерів на судні може бути представлено тривимірною матрицею, при вирішенні оптимізаційної задачі розміщення контейнерів на судні необхідно здійснювати послідовний аналіз їі стану для кожного із портів 3 метою зменшення шифтінгу (кількості контейнерів, що перезавантажуються);

- зміни у стані розміщення контейнерів на судні доцільно здійснювати на основі правил розвантаження та правил завантаження, представлених up і ур відповідно, що може бути здійснено за допомогою евристичних методів та процедур імітаційного моделювання.

Рисунок 1 важливий для ясного розуміння того, що розташування на контейнеровозі буде визначатися двома рішеннями в кожному порту: як розвантажити та як завантажити судно. У реальному житті розвантаження та завантаження контейнеровозів здійснюється відповідно до досвіду судноводія, проте значно ефективніше вирішувати цю проблему за допомогою програмних засобів, що виконують розміщення контейнерів на основі логічних правил та евристичних алгоритмів.

Таким чином, розташування вантажу на контейнеровозі при виході 3 кожного порту $p\left(x_{p+1}\right)$ залежить від схеми розміщення на контейнеровозі, коли він тільки прибуває до Порту $p\left(x_{p}\right)$, плюс скільки контейнерів розвантажується $\left(u_{p}\right)$ та завантажується $\left(y_{p}\right)$ в порту $p$.

Далі розглянемо, як представляти рішення оптимізаційної задачі формування вантажного плану контейнеровозу. При цьому будемо застосовувати спеціальний підхід до кодування / декодування, який поєднує в собі правила, що описують спосіб завантаження та розвантаження контейнеровозу, а також процедуру моделювання. Це кодування $є$ представленням за правилами.

Обчислювальна реалізація процесу розміщення за правилами залежить від визначення наступних елементів.

1. Оскільки контейнеровози мають модульну структуру, схема розташування на контейнеровозі може бути представлена матрицею $B$, 
яка називається матрицею стану, і ця матриця - це змінна, що відноситься до стану контейнеровозу $\left(x_{p} i x_{p+1}\right)$.

2. Зміни у стані контейнеровозу, здійснені за допомогою правил розвантаження (ПР) та правил завантаження (ПЗ), представлених $u_{p} \mathrm{i}$ $y_{p}$ відповідно, можуть бути виконані за допомогою процедури обчислювального моделювання.

Матриця $B$ - це схема розміщення на контейнеровозі, оскільки кожен елемент в $B$ представлений $B_{d r c}$, і він описує, чи це контейнер, пунктом призначення якого $є$ Порт $p$ в комірці, розташованій у рядку $r$, стовбці с i відсіку $d$, якщо $B_{d r c}=p$; якщо $B_{d r c}$ порожній, то $B_{d r c}=0$. Щоб краще це проілюструвати, матриця $B$, де $D=3$ i $R=C=2$, показана на рисунку 3 .

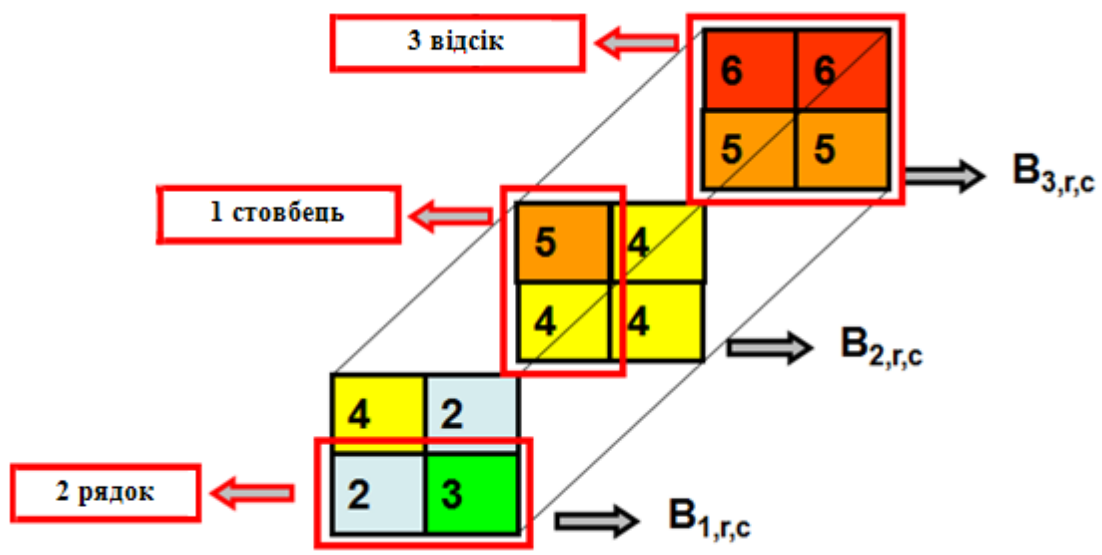

\section{Рис. 3. Матриця стану $B$, шо представляс розташування контейнерів у контейнеровозі при русі до 6 портів}

На рисунку 3 рядок 2 представляє нижню частину контейнеровозу, а рядок 1 - верхню частину контейнеровозу. Таким чином, елемент $(1,1,1)$ дорівнює 4 , що означає, що цей модуль зайнятий контейнером, пунктом призначення якого є порт 4. Використовуючи ті ж критерії, елемент $(3,2,2)$ дорівнює 5 , і це означає, що цей модуль зайнятий контейнером, призначенням якого є порт 5 .

Припускаючи, що матриця $B$ на рисунку 3 представляє контейнеровоз в порту 2 , для розвантаження цього контейнеровозу необхідно 
перемістити контейнери, розташовані в модулях $(1,2,1)$ та $(1,1,2)$. Однак контейнер у модулі $(1,2,1)$ може бути розвантажений лише якщо контейнер, розташований в комірці $(1,1,1)$, теж розвантажений; навіть незважаючи на те, що пунктом призначення цього контейнера $\epsilon$ Порт 4. Метою процесу завантаження контейнеровозу (ПЗК) є мінімізація кількості переміщень подібного роду шляхом адекватної схеми розміщення у відсіках контейнеровоза у кожному порту.

Таким чином, запропонований підхід розміщення контейнерів за правилами розглядає ПЗК як проблему, в якій матриця $B$ - це схема розміщення на контейнеровозі $\left(x_{p}\right)$, до прибуття в Порт $p$. Вона буде змінюватися у кожному порту шляхом визначення, як саме виконувати операції розвантаження $\left(u_{p}\right)$ та завантаження $\left(y_{p}\right)$, визначаючи ПР та П3 відповідно. Вибір ПР або ПЗ для порту 2 може опосередковано впливати на схему розміщення на контейнеровозі в Порту 4, оскільки графічне представлення ПЗК має форму, показану на рисунку 4.

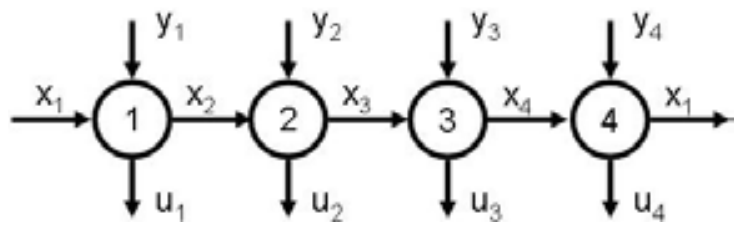

Рис. 4. Графічне представлення для ПЗК 3 чотирма портами призначення

Нами було визначено 6 основних правил завантаження контейнеровозу та 2 правила вивантаження, а саме:

Правило завантаження П31: за цим правилом матриця $B$ заповнюється рядок за рядком, зліва направо, починаючи з нижнього ряду для кожного відсіку таким чином, щоб контейнери з найостаннішим пунктом призначення були розміщені на найнижчих рядках, і кожен відсік заповнюється перед наступним.

Правило завантаження П32: за цим правилом матриця $B$ заповнюється рядок за рядком, зліва направо, починаючи з першого відсіку, i заповнюючи лише один рядок на відсік таким чином, щоб контейнери 3 найостаннішим пунктом призначення були розміщені в найнижчих рядках і розподілені між відсіками. 
Правило завантаження ПЗ3: це правило є зворотним ПЗ1, що означає, що матриця $B$ заповнюється рядок за рядком, справа наліво, починаючи 3 нижнього ряду для кожного відсіку таким чином, щоб контейнери 3 найостаннішим пунктом призначення були розміщені в найнижчих рядках і кожен відсік заповнюється перед початком наступного.

Правило завантаження П34: це правило є зворотним ПЗ2 в тому сенсі, що матриця $B$ заповнюється рядок за рядком, справа наліво, один рядок на відсік починаючи з першого відсіку, доки не досягне останнього таким чином, щоб контейнери 3 найостаннішим пунктом призначення розміщуються на найнижчих рядах і розподілялися між відсіками.

Правило завантаження П35: за цим правилом матриця $B$ заповнюється рядок за рядком зліва направо контейнерами, призначеними для найближчого порту, починаючи з першого відсіку та продовжуючи, доки в стовпчику не буде досягнуто кількість елементів $\theta_{p}$. Значення $\theta_{p}$ обчислюється за рівнянням:

$$
\Theta_{p}=\left[\frac{\sum_{i=1}^{P} \sum_{j=p+1}^{N} T_{i j}}{D^{*} C}\right] .
$$

Потім інший відсік заповнюється таким чином, щоб контейнери 3 найближчим призначенням були розміщені спочатку для формування штабелів.

Правило завантаження ПЗ6: це правило є зворотним ПЗ5 в тому сенсі, що матриця В заповнюється рядок за рядком справа наліво контейнерами, призначеними для найближчого порту, починаючи 3 першого відсіку і продовжуючи, доки не досягається кількість елементів $\theta_{p}$ у стовпчику. Значення $\theta_{p}$ також обчислюється за рівнянням (6).

Правило розвантаження ПР 1: припустимо, що контейнеровоз прибуває у Порт $p$. За цим правилом вилучаються лише контейнери, пунктом призначення яких є Порт $p$, і всі інші, що блокують штабель.

Правило розвантаження ПР2: це правило зазначає, що контейнеровоз повинен розвантажувати кожен контейнер при прибутті в певний Порт $p$ таким чином, щоб він міг повністю перебудувати кожен штабель. 
Щоб уникнути необхідності використання двох значень, щоб вказати, які ПЗ і ПР будуть використовуватися для кожного порту, можна спростити кодування, визначивши різні комбінації ПЗ і ПР. Конкретна комбінація ПЗ і ПР для Порту р визначається як правило ПП.

Щоб краще проілюструвати концепцію правил, шість ПЗ і два ПР, описані вище, можуть бути об'єднані для створення нових 12 правил. Таблиця 1 ілюструє всі правила, створені в результаті цих комбінацій ПЗ та ПР.

Таблиця 1

Правила, створені шляхом посднання ПЗ та ПР

\begin{tabular}{|c|c|c|}
\hline Правила завантаження & $\begin{array}{c}\text { Правила } \\
\text { розвантаження }\end{array}$ & Підсумкове правило \\
\hline \multirow{2}{*}{ П31 } & $\overline{\Pi \text { ПР1 }}$ & ПП1 \\
\hline & ПР2 & ПП2 \\
\hline \multirow{2}{*}{$\Pi 32$} & ПР1 & ППЗ \\
\hline & ПР2 & ПП4 \\
\hline \multirow{2}{*}{$\Pi 33$} & ПР1 & ПП5 \\
\hline & ПР2 & ПП6 \\
\hline \multirow{2}{*}{ П34 } & ПР1 & ПП7 \\
\hline & $\overline{\Pi Р 2}$ & ПП8 \\
\hline \multirow{2}{*}{ П35 } & ПР1 & ПП9 \\
\hline & ПР2 & ПП10 \\
\hline \multirow{2}{*}{ П36 } & ПР1 & ПП11 \\
\hline & ПР2 & ПП12 \\
\hline
\end{tabular}

В таблиці 1 показані різні комбінації ПЗ і ПР. Наприклад, правило 2 це комбінація правила розвантаження ПР2 та правила завантаження ПЗ1. Це кодування необхідне для представлення рішення ПЗК, в якому використовується вектор, число елементів якого дорівнює кількості портів.

Для збереження умов остійності судна необхідно додатково обчислювати суму відстані між центром маси та геометричним центром контейнеровозу у кожному відсіку $d$ у кожному порту.

Для вирішення оптимізаційної задачі ПЗК з використанням логічних правил нами застосовуються методи імітаційного моделювання та евристичні методи, якими визначаються набори логічних правил та послідовність їх застосування. 
Найбільш ефективним та відносно нескладним 3 евристичних методів в плані практичної реалізації, враховуючи існуючі програмні продукти (Mathlab, Simulink) тощо нами були обрані генетичні алгоритми (ГА).

Відповідно вирішення проблеми оптимального завантаження контейнеровозу було розроблено ГА з наступною структурою.

Структура ГА. ГА використовує сукупність елементів, що представляють собою: $A(t)=\left\{A_{1}^{t}, \ldots, A_{n}{ }_{n}^{t}\right\}$ для кожної генерації (ітерації) $t$, в якій кожен елемент - це вектор правил. У процесі обчислення, сукупність елементів зберігається в матриці $A(t)$, і кожен рядок $A_{i}^{t}$ представляє цей вектор правил. Кожен вектор $A_{i}^{t}$ оцінюється за кількістю переміщень та показником остійності. Далі розраховується придатність, тобто міра того, наскільки успішним $є$ цей елемент в задачі розміщення.

Придатність розраховується для всієї сукупності і грунтується на цій новій сукупності, яка поєднує в собі найбільш ефективні елементи, які утворюють сукупність $t+1$. Під час формування нової сукупності деякі елементи з сукупності $\mathrm{t}$ надаються процесом перетворення генетичними операторами для формування нових правил.

Ці перетворення включають в себе унарні операції $m_{i}$ (мутації), які дозволяють створювати нові правила за допомогою невеликих змін окремих атрибутів $\left(m_{i}: A_{i} \rightarrow A_{i}\right)$ і перетворення верхнього порядку с (кросовер), що генерує нові елементи, об'єднуючи один або декілька елементів $\left(c_{j}: A_{j} \times \ldots \times A_{k} \rightarrow A_{j}\right)$.

Зазначений процес здійснюється до досягнення визначеної раніше попередньої кількості генерацій. Наступним важливим етапом $є$ кодифікація структури даних для кожного окремого елемента.

Кодифікаиія структури даних для кожного окремого елемента. Кожний елемент ГА асоціюється з набором правил за допомогою вектора v, наприклад, чотирьохелементного. Значення всередині елементів відповідають кожній комбінації розвантаження та ПЗ (від ПП1 до ПП12), яка буде застосовуватися у кожному Порту (від 1 до 4). Набір правил для різних елементів зберігається в матриці, а кожен стовпець представляє окремий елемент, показано на рисунку 5, де перший стовпець містить чотирьохелементний вектор $\mathrm{v}_{1}$, в якому кожне значення відповідає таблиці 1. 
Матриця $A$ має два вектори $v_{1}$ i $v_{2}$. Коли елемент визначено, то також може бути визначено сукупність, яка складається з елементів, що зберігаються в матриці $A$. Оскільки кожен стовпець матриці $A$ представляє елементи / рішення, кожен елемент $A(i, j)=k$ визначає, яке правило $k$ ( $k$ дорівнює $1-12)$ в Порту $i$ буде використовуватися, якщо вибрати елемент $j$. Наприклад, $A(1,1)=6$ означає, що елемент / рішення 1 у Порту 1 повинен застосувати правило ПП6, тобто розвантаження контейнеровозу за ПР2 та завантаження за ПЗ3.

Очінка придатності рішення чи доиільність варіанта розміщення відповідає за

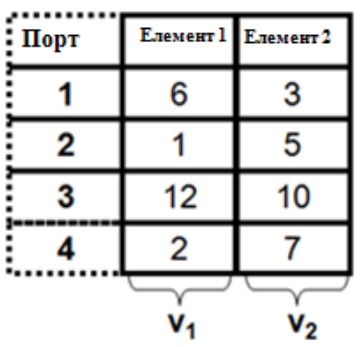

Рис. 5. Відношення між кодуванням елементів ГА та набором правил для кожного елемента (вектор стовпця) оцінку елементу в межсах сукупності в генерації $t$. Таким чином, придатність рішення побудована так, що рішення з меншим показником мають вищі показники придатності:

$$
\text { Fit }\left(A_{i}\right)=f\left(A_{i}\right) \text {, }
$$

де $f\left(A_{i}\right)$ - оцінка придатності, згідно з комбінацією кількості переміщень та показника нестабільності,

Іншими словами, вона транслює рішення, запропоновані набором правил, що зберігаються в векторі $A_{i}$, 3 точки зору кількості переміщень рівняння та показника нестабільності шляхом моделювання схеми розташування контейнерів в контейнеровозі, коли він подорожує від порту до порту. Наступним кроком $\epsilon$ вибір елементів для формування наступної генерації.

Вибір елементів для наступної генерації. Процес формування сукупності - це випадковий вибір («колесо рулетки»), де ймовірність $Q$ $\left(A_{i}\right)$ використовується для вибору елементу $A_{i}$ для наступної генерації в сукупності з елементами $b$. Значення $Q\left(A_{i}\right)$ можна отримати, використовуючи рівняння (8).

$$
\mathrm{Q}\left(A_{i}\right)=\operatorname{Fit}\left(A_{i}\right) / \sum_{i=1}^{\text {numpop }}\left(\text { Fit }\left(A_{i}\right)\right) .
$$

Найкращий елемент поточної генерації завжди залишається в наступній генерації. 3 метою отримання нових елементів застосовуються оператори кросовера і мутації. 
Кросовер. Оператори кросовера генерують нові елементи для формування наступної сукупності шляхом об'єднання інформації з минулих генерацій, яка присутня в елементах. Тут використовуються два оператора кросовера, які описуються наступним чином.

Два елемента, $A_{1}$ та $A_{2}, 3 N$ елементами, випадковим чином обираються з сукупності у генерації $t$. Потім формується ціле число $\delta$ в інтервалі [1, $N$-1], а елементи $A_{l}$, що знаходяться в положеннях $\delta$ до $N$ обмінюються елементами $3 A_{2}$, які розташовані в положенні $\delta$ до $N$. Цей обмін дасть два нових елементи, $n A_{1}$ і $n A_{2}$, які можуть 3'явитися в наступній генерації.

Структура розробленого ГА має вигляд, наведений на рисунку 6.

Оператор мутації. Оператор мутації змінює рm елементів матриці $A$, де $p m$ - відсоток сумарних бітів, які мутують.

Вибір того, який елемент $A_{i j}$ мутується, полягає у випадковому виборі індексу рядка та індексу стовпця, а потім їхній зміні, при цьому розмір підсукупності $A s_{1}{ }^{t}$ та $A s_{2}{ }^{t}$ однаковий і дорівнює 5\% від загальної сукупності.

Запропонований новий комбінований підхід до задачі тримірного планування завантаження контейнеровозів, що має наступні переваги:

- дозволяе здійснювати компактне кодування, представляючи рішення як вектор з елементами Р замість двійкових змінних $(R x C) x\left(P+P^{3}\right)$, що дає можливість спростити обробку даних на вирішення проблеми з оптимального розміщення контейнерів;

- досвід кваліфікованого персоналу може бути включений в процес оп-тимізації у формі правил та обчислювального моделювання;

- формування рішення з використанням запропонованих математичних моделей завжди є можливим, та дозволяє уникнути проблеми подовженого часу обробки.

- новий підхід до кодування значно зберігає час на обчислення i дозволяє формувати якісні рішення з розміщення контейнерів на судні.

На основі розроблених математичних моделей нами було створено прототип АСУВОК, яка здатна істотно полегшити и контроль за завантаженням / вивантаженням фідерного контейнеровоза.

Робота системи здійснюється наступним чином. При заході контейнеровоза (3) в порт здійснюється підключення по мережі wifi (2) судової системи підтримки прийняття рішення (5) контейнеровоза до 


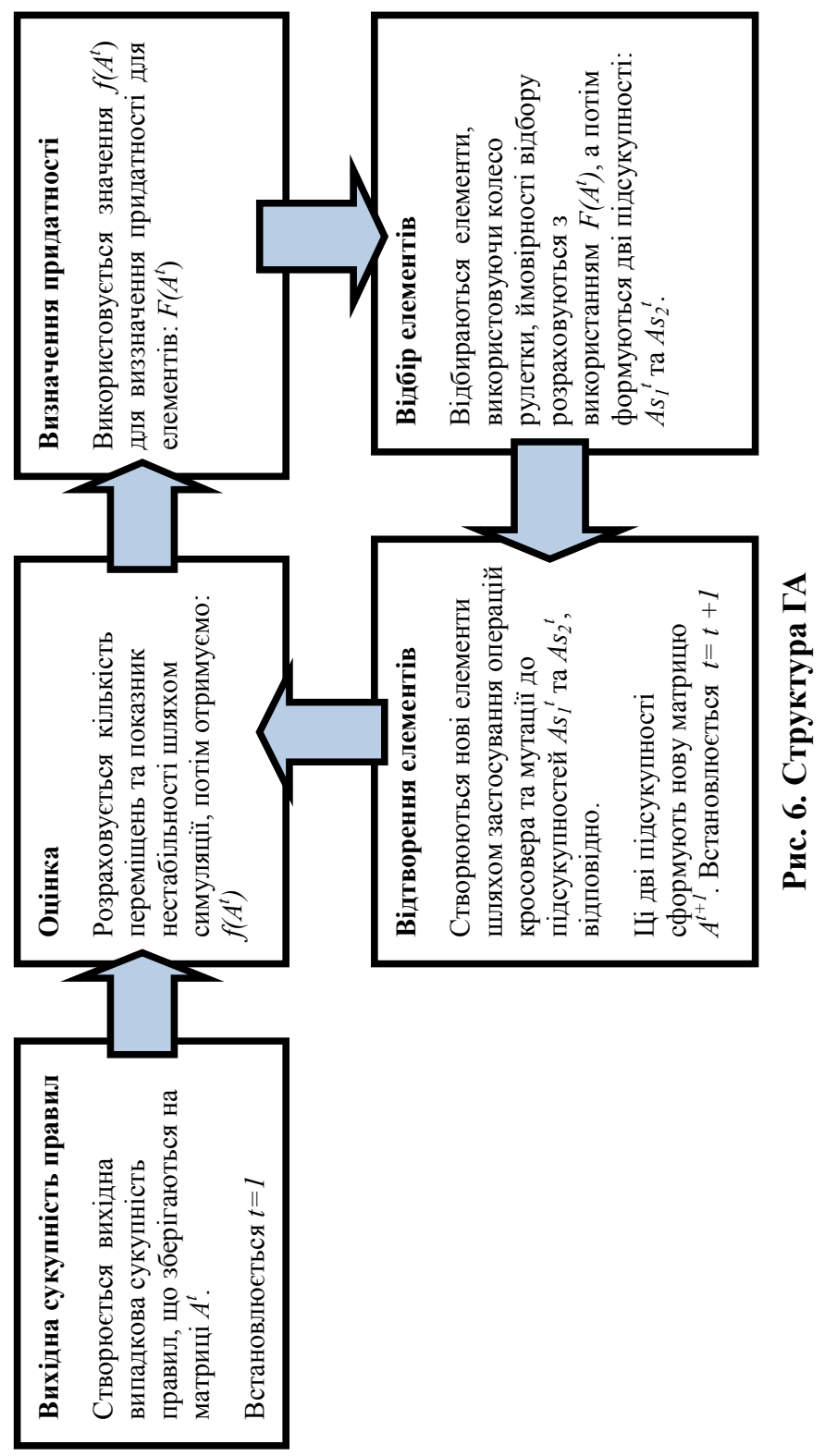


мережі Інтернет, в яку вже підключені комп'ютери (4) причальних контейнерних перевантажувачів (1). Відбувається реєстрація в мережі і план завантаження відображається на комп'ютері перевантажувача. Піднятий контейнер зважується вагами перевантажувача, і інформація про усі параметри надходить через мережу Інтернет в суднову інформаційну систему. Такім чином, АСУВОК дозволяє капітану судна оперативно оцінити ступінь його завантаження, зменшити простої, $\mathrm{i}$ забезпечити безпеку перевезень. При цьому використовуються новітні технології передачі інформації, зокрема технології zigbee.

Структура АСУВОК наведена на рисунку 7. Слід зазначити, що відмінними рисами розробленої автоматизованої системи є їі відносно невелика вартість, а також орієнтованість до застосування на фідерних перевезеннях (особливістю фідерних перевезень $є$ мультипортовість та невелика кількість контейнерів на судні: 600-1200). Кількість програмних продуктів, що забезпечують вирішення даного класу задач на поточний момент часу обмежена.

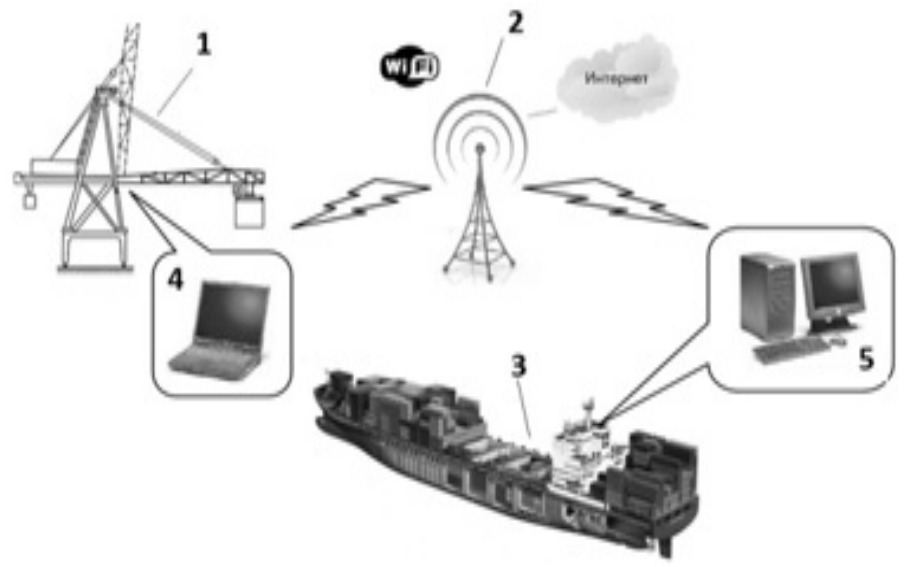

Рис. 7. Структура АСУВОК

Структура АСУВОК: 1 - контейнерний перевантажувач; 2 - станція $\mathrm{WiFi} ; 3$ - контейнеровоз; 4 - ноутбук в кабіні контейнерного перевантажувача; 5 - персональний комп'ютер у складі суднової автоматизованої системи, на якому розташована система підтримки прийняття рішень. 


\section{4. Висновки}

Підсумовуючи підсумки проведеного аналізу наукових досліджень вітчизняних та закордонних авторів у зазначеній галузі, було з'ясовано, що питання створення інтелектуальних автоматизованих систем управління процесами завантаження-вивантаження контейнеровозів $\epsilon$ актуальною науковою проблемою сьогодення, яка потребує вирішення з урахуванням нагальних поточних потреб морської індустрії.

Створення нових методів або алгоритмів оптимізації процесу складання вантажного плану судна типу контейнеровоз $є$ одним з найбільш актуальних питань сьогодення. Аналіз, який проведено у даній роботі, дозволив розробити власну модель і алгоритм розміщення контейнерів на судні, що оптимізує процес складання вантажного плану судна сприяє підвищенню безпеки контейнерних перевезень.

Застосування пропонованого підходу до побудови вантажного плану контейнеровозу дозволяє також поліпшити економічні показники виконання судном рейсу за рахунок зменшення часу виконання вантажних операцій та тривалості стоянки судна в портах.

Визначено, що в умовах запровадження сучасних інформаційних технологій в судноводінні найважливішою складовою підвищення ефективності та безпечності контейнерних перевезень стає створення АСУВОК. При створенні таких систем необхідно враховувати, що найвагомішим чинником аварійності сучасного судноплавства, $\epsilon$ так званий «людський фактор», тому при створенні таких систем особлива увага має бути приділена саме зниженню суб'єктивності прийняття рішень при формуванні вантажних планів контейнеровозів.

Таким чином, в сучасних умовах впровадження АСУВОК здатна істотно підвищити ефективність здійснення контейнерних перевезень та знизити аварійність сучасного судноплавства.

В цілому слід зазначити, що на даному етапі світова контейнерна система вимагає узгодженого розвитку - має бути забезпечене не тільки будівництво нових ультрасучасних суден а й модернізація існуючих, будівництво нових великих спеціалізованих портів і терміналів, створення великовантажних типів розвантажувально-вантажної техніки. Необхідний також контроль за пересуванням контейнерів як в порту так і протягом усього шляху у морі і на суші, узгодженість країн-партнерів з торгівлі, що ще більше ускладнює проблему, перетворюючи іiі, по суті, в глобальну. 


\section{Список літератури:}

1. Dyckhoff, H. (1990). A typology of cutting and packing problems. European Journal of Operational Research, 44, 2, 145-159.

2. Fan, L., Low, M.Y.H., Ying, H.S., Jing, H.W., Min, Z., \& Aye, W.C. (2010). Stowage planning of large containership with tradeoff between crane workload balance and ship stability. Proceedings of the International MultiConference of Engineers and Computers Scientists, III, 1-7.

3. Imai, A., Sasaki, K., Nishimura, E. and Papadimitriou, S. (2006). Multiobjetive simultaneous stowage and loading planning for a container ship with container rehandle in yard stacks. European Journal of Operational Research, 171, 3, 373-389.

4. Vacca, I., Bierlaire, M., \& Salani, M. (2007). Optimization at container terminals: status, trends and perspectives. 7-th Swiss Transportation Research Conference, September, 1-21.

5. Sciomachen, A., \& Tanfani, E. (2007). A 3D-BPP approach for optimizing stowage plans and terminal productivity. European Journal of Operational Research, 183, 3, 1433-1446.

6. Wilson, I., \& Roach, P.A. (1999). Principles of combinatorial optimization applied to container-ship stowage planning. Journal of Heuristics, 5, 4, 403-418.

7. Valente, J.M.S., \& Alves, R.A.F.S. (2005). Filtered and recovering beam search algorithm for the early/tardy scheduling problem with no idle time. Computers \& Industrial Engineering, 48, 2, 363-375.

8. Ribeiro, C.M., Azevedo, A.T., \& Teixeira, R.F. (2010). Problem of assignment cells to switches in a cellular mobile network via beam search method. WSEAS Transactions on Communications, 9, 1, 11-21.

9. Michalewicz, Z. (1996). Genetic Algorithms + Data Structures $=$ Evolution Programs. London : Springer-Verlag.

10. Dubrovsky, O., Levitin, G., \& Penn, M. (2002). A genetic algorithm with a compact solution encoding for the containership stowage problem. Journal of Heuristics, 8, 6, 585-599. 